\title{
Concentrations of progesterone in the backfat of pigs during the oestrous cycle and after ovariectomy*
}

\author{
F. W. Hillbrand and F. Elsaesser \\ Institut für Tierzucht und Tierverhalten (FAL), Mariensee, 3057 Neustadt 1, \\ Federal Republic of Germany
}

\begin{abstract}
Summary. Small samples of backfat were taken daily during one oestrous cycle and more frequently after ovariectomy from 12 gilts by means of a simple biopsy technique and the levels of progesterone were determined. Compared to the levels of progesterone in peripheral plasma changes in backfat levels during the oestrous cycle were delayed by 1-2 days. Maximal levels with $89 \cdot 7 \pm 9 \cdot 2$ (mean \pm s.e.m.) ng progesterone $/ 100 \mathrm{mg}$ backfat were recorded on Day 15 of the oestrous cycle. It was estimated that, on this day, a total amount of about $36 \mathrm{mg}$ progesterone is stored in the adipose tissue, which is approximately 200 times that present in total blood and corresponds to the daily production of the corpora lutea of the sow on Day 11.

Initial half-life of progesterone in backfat after ovariectomy was estimated to be about $34 \mathrm{~h}$ compared to an initial half-life of plasma progesterone of about $120 \mathrm{~min}$. The exact calculation of half-lives was, however, confounded by an obvious effect of anaesthesia or surgery on progesterone levels. Changes in backfat or plasma progesterone concentrations were not affected by the fat-to-lean ratio of the gilts.

Fat progesterone levels determined in 44 additional pregnant and non-pregnant sows 17 or 20 days after mating indicated that reliable diagnosis of non-pregnant sows was possible on Day 20.

It is concluded that the endocrinology of the oestrous cycle in pigs is related to the enormous storage of progesterone in the fat.
\end{abstract}

\section{Introduction}

Changes in plasma progesterone levels associated with oestrous cyclicity in the pig have been well documented but the relationship between these changes in peripheral circulating progesterone levels and the functional activity of the corpora lutea raises some questions. The determination of progesterone levels in ovarian venous plasma (Gomes, Herschler \& Erb, 1965; Masuda, Anderson, Henricks \& Melampy, 1967) and the measurement of progesterone secretion rates by the ovary (Brinkley \& Young, 1968) lead to the conclusion that the maximum in secretory activity of the corpora lutea occurs between Days 8 and 12 of the oestrous cycle. Peripheral levels of progesterone, however, start to decline on Day 13 or 14 (for references see Foxcroft \& van de Wiel, 1982) and therefore do not seem to reflect the functional activity of the corpora lutea accurately. This delayed decline in peripheral concentrations suggests that progesterone is stored in body tissue and released from these reservoirs following the onset of luteolysis. Due to its lipophilic nature, progesterone is probably stored primarily in body fat and high concentrations of progesterone have been observed

* Reprint requests to Dr F. Elsaesser.

0022-4251/83/050080-08\$02-00/0

(C) 1983 Journals of Reproduction \& Fertility Ltd 
in adipose tissue of women (Kaufmann \& Zander, 1956) and cows (McCracken, 1964; Schmidt, Hoffmann \& Rattenberger, 1977). Because of the physiological significance of any storage of progesterone in adipose tissue, particularly in a species such as the pig with a high fat-to-lean ratio, it was decided to study the dynamics of progesterone storage and depletion from backfat during the oestrous cycle and after ovariectomy.

\section{Materials and Methods}

\section{Animals and sampling of blood and fat}

German Landrace gilts $(\mathrm{N}=12)$ were kept individually in farrowing crates and received a standard pig chow and water. Just before (2-3 days) the beginning of the experiments (mean body weight at that time $140 \mathrm{~kg}$, mean age 285 days) all gilts were equipped surgically with indwelling jugular catheters as described previously by Ellendorff, Parvizi, Elsaesser \& Smidt (1977).

Backfat samples $(\sim 20 \mathrm{mg}$ ) were obtained with a biopsy needle (Fa. Henke, Sass, Wolff, F.R.G.; diam. $1.8 \mathrm{~mm}$, length $70 \mathrm{~mm}$ ) used in human medicine for liver biopsy. The needle was inserted vertically through the skin and then advanced horizontally for $2-4 \mathrm{~cm}$. The fat samples were taken from the area above the $\mathrm{m}$. longissimus dorsi $2-5 \mathrm{~cm}$ left or right from the dorsal midline. Before removing the needle a slight vacuum was produced with a syringe connected to the needle. The fat sample was pushed into a small vial by the pressure of the syringe or, better, a fine stick and stored at $-20^{\circ} \mathrm{C}$ until analysis. The sampling procedure lasted $2-3 \mathrm{~min}$ and no restraint of inexperienced animals was necessary. No anaesthetics or disinfectants were used. The biopsy needles were thoroughly cleaned and sterilized $\left(2 \mathrm{~h}\right.$ at $\left.200^{\circ} \mathrm{C}\right)$ between each sampling.

One daily blood and fat sample was taken between 10:00 and 12:00 h for 24 days. Occurrence of oestrus was checked once daily by observation of vulval swelling and by exerting pressure on the back of the gilts. The first day of standing heat was defined as Day 0 of the oestrous cycle.

Ten of the gilts were ovariectomized 12 or 13 days after the first day of standing oestrus. The other 2 gilts were ovariectomized at random stages. Each animal received $2 \mathrm{ml}$ azaperone (Stresnil) and $8 \mathrm{ml}$ metomidate (Hypnodil; both products from Janssen Pharmaceutica, Düsseldorf, F.R.G.) through the catheter. The abdomen was opened and at exactly $20 \mathrm{~min}$ after the injection the ovariectomy was performed. Blood samples were taken at 10-min intervals from $1 \mathrm{~h}$ before to $2 \mathrm{~h}$ after the onset of anaesthesia and then at less frequent intervals (see Text-figs 3 and 4). Backfat samples were obtained immediately following the injection of the anaesthetic and $5,12,23,35,47$, 71 and $95 \mathrm{~h}$ later.

On the 6th day after ovariectomy all gilts received $6 \mathrm{i} . \mathrm{m}$. injections of $50 \mathrm{mg}$ progesterone in oil (Progesterone IBV, Albrecht, Aulendorf, $25 \mathrm{mg}$ progesterone $/ \mathrm{ml}$ ) at 8-h intervals, corresponding to about $1 \mathrm{mg}$ progesterone $/ \mathrm{kg}$ body weight each day. Blood and fat samples were taken at intervals as indicated in Text-fig. 5 .

At 8 days after the first injection of progesterone the sows were slaughtered and the percentage of fat tissue and the fat-to-lean ratio were determined by planimetry of the longissimus dorsi and the surrounding adipose tissue behind the $13 \mathrm{th}$ rib, as described by Kallweit (1978). From 44 additional sows, kept at an experimental farm, backfat samples were taken 17 and 20 days after mating, and the progesterone content of the fat was analysed.

\section{Hormone analyses}

Plasma. Plasma progesterone levels after ovariectomy and treatment with progesterone were measured by a specific radioimmunoassay following extraction with hexane-ethyl acetate $(99: 1$ $\mathrm{v} / \mathrm{v}$ ) as described by Parvizi, Elsaesser, Smidt \& Ellendorff (1976), except that the antiserum (P/3) had been raised against progesterone-1 $1 \alpha-$ BSA and cross-reacted $\leqslant 3 \cdot 2 \%$ with desoxycorticosterone, $\leqslant 0.3 \%$ with testosterone, and $\leqslant 0.1 \%$ with $17 \alpha$-hydroxyprogesterone, hydrocortisone 
and oestradiol-17 7 . The actual inter- and intra-assay coefficients of variation in these experiments were 15.6 and $7 \cdot 3 \%$, respectively. The sensitivity of the assay, defined as the smallest amount detectable from 0 , was $50 \mathrm{pg} / \mathrm{ml}$.

Plasma progesterone concentrations during the oestrous cycle were determined directly in $20 \mu \mathrm{l}$ plasma by a rapid RIA without prior extraction. The plasma was diluted with $200 \mu$ phosphatebuffered saline containing $1 \%$ of bovine $\gamma$-globulin (Behring) and incubated for $30 \mathrm{~min}$ at room temperature. The following steps were identical to those of the reference method. Single samples of plasma from 176 pregnant or non-pregnant sows 17-20 days after mating were assayed by this method and the above mentioned RIA described previously (Parvizi et al., 1976). Regression analysis gave a slope of 0.85 and a coefficient of correlation of 0.93 . The intercept was 1.74 . The inter- and intra-assay coefficients of variation were 15.2 and $5-9 \%$ (depending on the progesterone concentration), respectively. The sensitivity of this assay, defined as the smallest amount detectable from 0 , was $500 \mathrm{pg} / \mathrm{ml}$.

Backfat. Approximately $10 \mathrm{mg}$ fat were prepared from the biopsy material, weighed on weighing paper, and transferred to a glass-stoppered extraction vial. Extraction was performed twice with $4 \mathrm{ml}$ petroleum ether (Merck, boiling range $50-70^{\circ} \mathrm{C}$ ) and the samples were shaken for 30 $\min$ at $40^{\circ} \mathrm{C}$. The petroleum ether extract was evaporated under reduced pressure and at increasing temperatures $\left(20-40^{\circ} \mathrm{C}\right)$. The extract was redissolved in $4 \mathrm{ml}$ petroleum ether and then $4 \mathrm{ml}$ methanol : water $(80: 20 \mathrm{v} / \mathrm{v})$ were added and shaken for $2 \mathrm{~min}$. Progesterone was extracted by the methanol : water phase and fat remained in the petroleum ether. The petroleum ether was removed and discarded and the partition was repeated by adding $4 \mathrm{ml}$ fresh petroleum ether. The methanol phase was evaporated under reduced pressure and at increasing temperatures $\left(20-50^{\circ} \mathrm{C}\right)$ and the RIA of progesterone was performed with an aliquant representing $10-40 \%$ of the fat extract as described above. Procedural losses were corrected by incubation with $\left[{ }^{3} \mathrm{H}\right]$ progesterone before extraction with petroleum ether.

When fat from castrated boars was analysed, the concentration of progesterone was $0.6 \pm 0.3$ $\mathrm{ng} / 100 \mathrm{mg}$ fat. Addition of 100,500 and $1000 \mathrm{pg}$ progesterone to $10 \mathrm{mg}$ fat containing $3.50 \mathrm{ng}$ progesterone $/ 100 \mathrm{mg}$ fat resulted in recoveries of $106 \pm 31,523 \pm 140$ and $977 \pm 220 \mathrm{pg}$ (mean \pm s.d., $\mathrm{N}=5$ ) respectively. Parallelism between the standard and unknown samples was demonstrated by using increasing aliquants of a fat extract: the concentrations of progesterone measured in 10,20 and $40 \%$ aliquants were $60.3 \pm 9.4,55.4 \pm 7.0$ and $58.7 \pm 1.9 \mathrm{ng}$ progesterone/ $100 \mathrm{mg}$ back fat, respectively (mean \pm s.d., $\mathrm{N}=5$ ). The sensitivity of this method, defined as the smallest amount detectable from 0 , was $300 \mathrm{pg} / 100 \mathrm{mg}$ fat. The calibration curve was fitted by a computer (LKB Rackbeta 1215 with on-line spline function calculation). All concentrations were calculated as the mean of duplicate aliquants.

\section{Results}

Mean concentrations of progesterone in backfat during the oestrous cycle are shown in Text-fig. 1 for those gilts $(\mathbf{N}=8)$ in which regular changes in progesterone levels indicated the occurrence of ovulation. Four animals had to be excluded from the calculation of the mean because the progesterone levels were constantly low $(\mathrm{N}=2)$ or constantly elevated $(\mathrm{N}=1$, cystic ovaries at ovariectomy) or because the sow stopped cycling (see Text-fig. 2). The maximum backfat progesterone value ( $89.7 \pm 9 \cdot 2 \mathrm{ng}$ (s.e.m.) $/ 100 \mathrm{mg}$ backfat) was recorded on Day -6 . Thereafter the levels steadily decreased for the next 7 days. Between Days -4 and -2 the progesterone concentration in backfat decreased to half its value within about $24 \mathrm{~h}$. A first clear increase above values at oestrus was observed on Day +5 . The slope of the increase was less than that of the decrease. For comparison, changes in plasma progesterone concentrations during the oestrous cycle are also shown in Text-fig. 1. Plasma progesterone levels started decreasing about 1 day before those in backfat and basal levels were reached about 2 days before fat progesterone reached its minimum. 


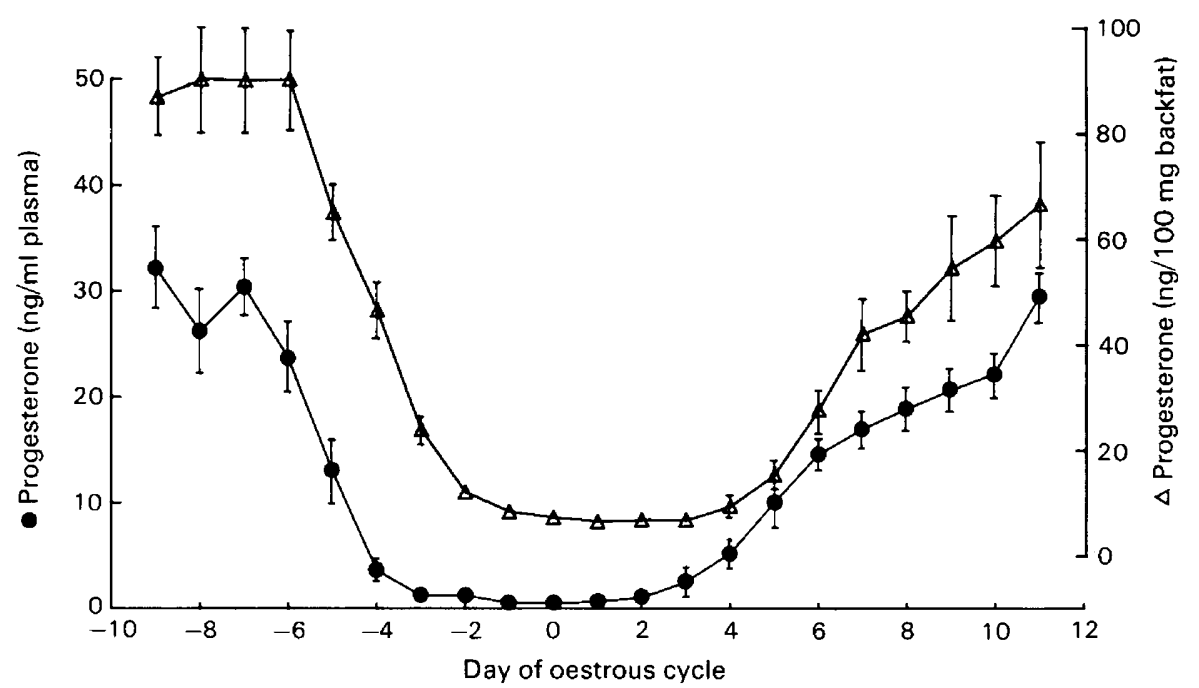

Text-fig. 1. Changes in mean \pm s.e.m. concentrations of progesterone in backfat and peripheral plasma during the oestrous cycle of 8 gilts. Designations of s.e.m. smaller than the symbols depicting the data points are not shown.
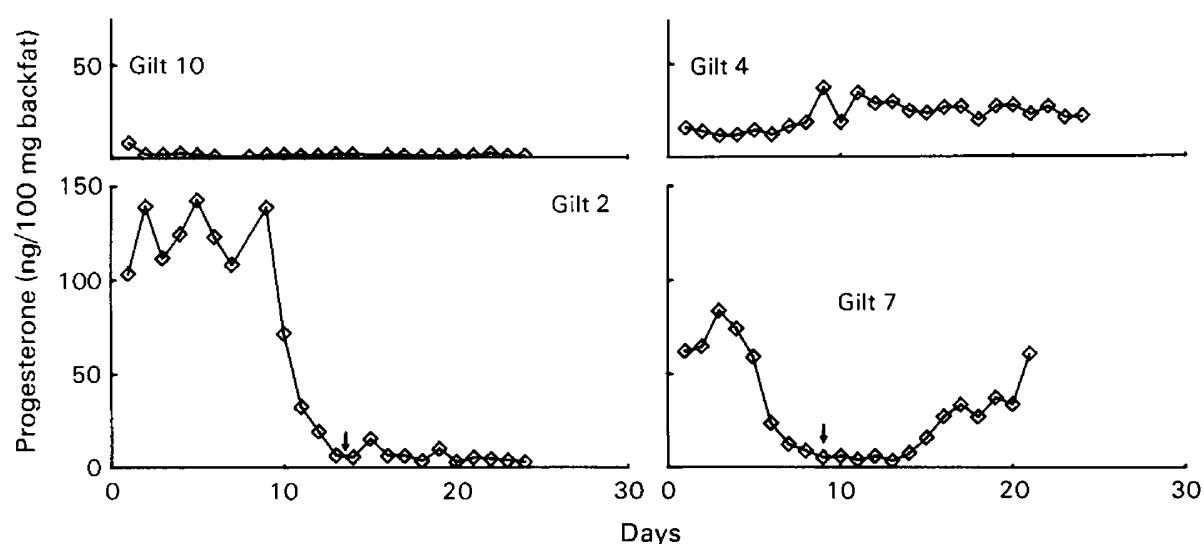

Text-fig. 2. Changes in concentrations of progesterone in backfat in individual gilts. Gilt 7 is representative for normal cyclic ovarian function, Gilt 10 is an example of delayed puberty, Gilt 2 stopped cycling for unknown reasons and Gilt 4 had 10 corpora lutea and 5 cystic follicles at ovariectomy. The arrow $(\downarrow)$ indicates the first day of oestrus.

After oestrus, plasma progesterone started to increase ( $\sim 2$ days) earlier than did progesterone in fat. Individual examples of changes in levels of progesterone in fat are given in Text-fig. 2.

The mean decrease in the concentration of progesterone in backfat after ovariectomy on Day 12 or 13 of the cycle is shown in Text-fig. 3 for those gilts $(\mathbf{N}=8)$ in which regular changes in progesterone concentrations had been observed and in which the appearance of the corpora lutea and the plasma level of progesterone corresponded to Day 12 or 13 of the cycle. After a nonsignificant increase at $5 \mathrm{~h}$, the progesterone level steadily decreased. At $95 \mathrm{~h}$ the levels were still above those at oestrus $(8.3 \pm 0.9$ compared with $6.2 \pm 0.5 \mathrm{ng}$ progesterone $/ 100 \mathrm{mg}$ backfat $)$. Initial half-life was estimated to be $34 \mathrm{~h}$. At $144 \mathrm{~h}$ after ovariectomy progesterone values had further decreased to $6.3 \pm 0.9 \mathrm{ng} / 100 \mathrm{mg}$ fat.

The corresponding changes in plasma progesterone (Text-fig. 3) indicate an initial rapid fall 
followed by a more gradual decline and a much shorter initial half-life for progesterone in plasma than in fat tissue. Plasma progesterone decreased from its initial value just before ovariectomy $(34 \cdot 2$ $\pm 2.4 \mathrm{ng} / \mathrm{ml}$ ) to $17.1 \mathrm{ng} / \mathrm{ml}$ within $120 \mathrm{~min}$. A further decrease to half of this occurred within the next $240 \mathrm{~min}$. Levels 95 and $144 \mathrm{~h}$ after ovariectomy were $1.1 \pm 0.4$ and $0.5 \pm 0.2 \mathrm{ng}$ progesterone $/ \mathrm{ml}$ plasma, respectively.

The changes in plasma progesterone levels in the 3 animals that had not ovulated and, consequently, had low levels of progesterone at the time of ovariectomy are shown in Text-fig. 4. After anaesthesia the progesterone levels increased (following a short decrease after

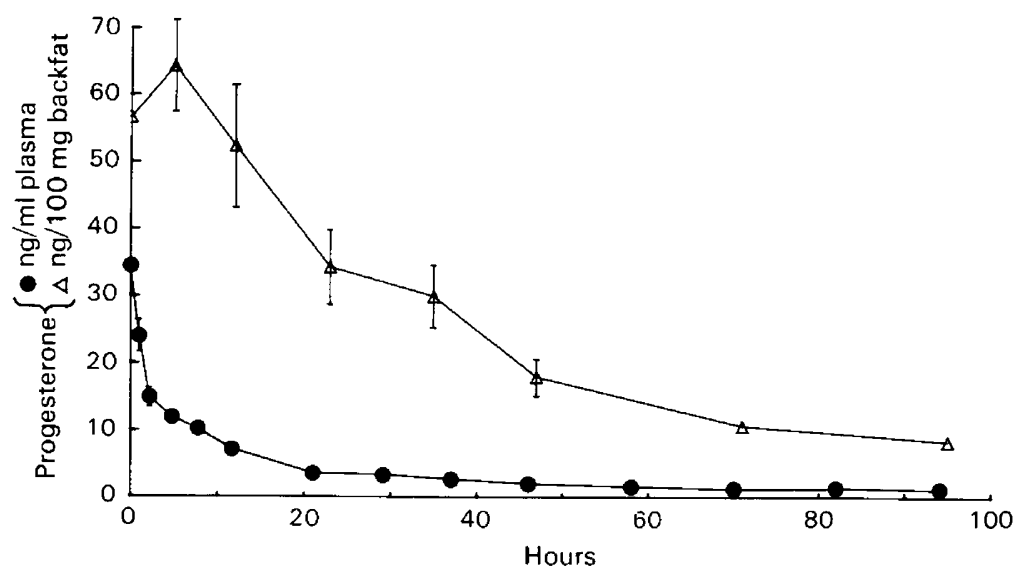

Text-fig. 3. Changes in mean \pm s.e.m. concentrations of progesterone in backfat and peripheral plasma after ovariectomy on Day 13 of the oestrous cycle in 8 gilts, which had normal functional corpora lutea at the time of ovariectomy. Designations of s.e.m. smaller than the symbols depicting the data points are not shown.

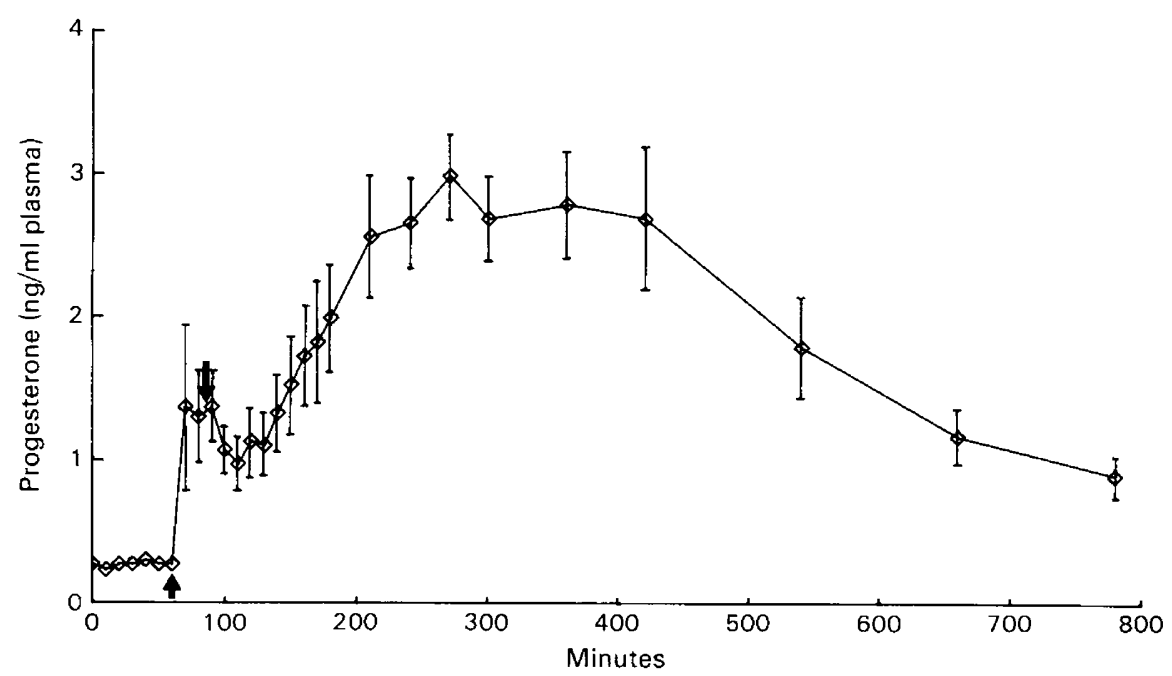

Text-fig. 4. Changes in mean \pm s.e.m. concentrations of progesterone in peripheral plasma after ovariectomy in 3 gilts that had no functional corpora lutea at the time of ovariectomy. The arrows indicate onset of anaesthesia by i.v. injection of $2 \mathrm{ml}$ azaperone and $8 \mathrm{ml}$ metomidate $(\uparrow)$ and time of ovariectomy $(\downarrow)$. Designations of s.e.m. smaller than the symbols depicting the data points are not shown. 


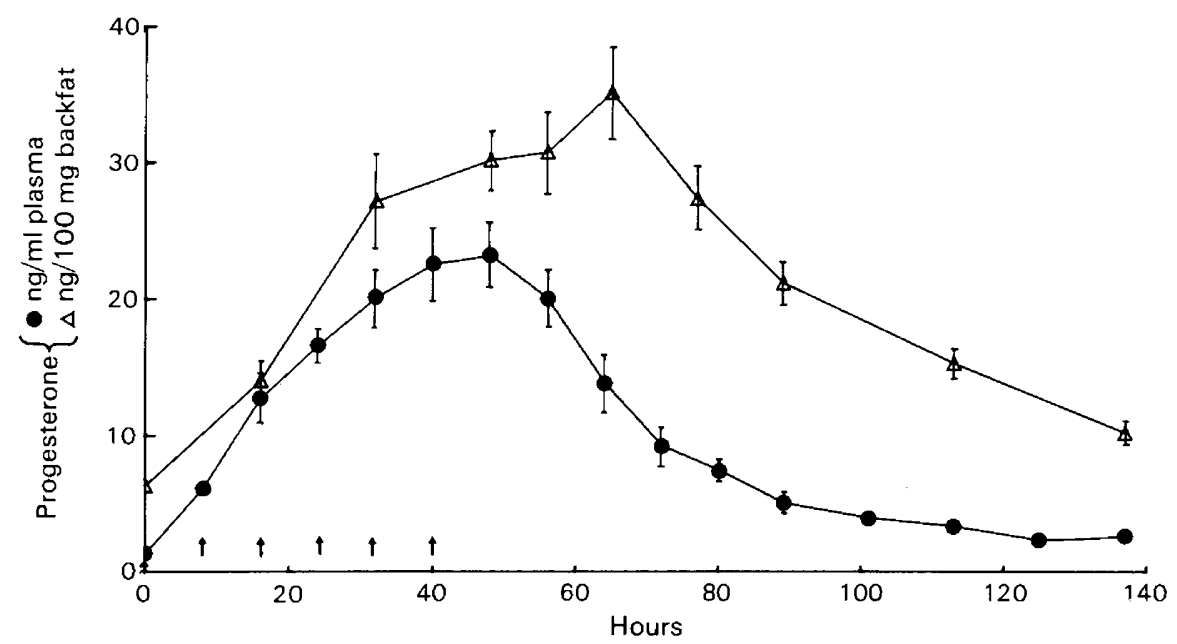

Text-fig. 5. Changes in mean \pm s.e.m. concentrations of progesterone in backfat and peripheral plasma in 12 ovariectomized gilts after repeated i.m. injections of $50 \mathrm{mg}$ progesterone $(\uparrow)$. Designations of s.e.m. smaller than the symbols depicting the data points are not shown.

ovariectomy) to reach a maximum of $3.0 \pm 0.3 \mathrm{ng} / \mathrm{ml}$ at $190 \mathrm{~min}$ after operation, but basal levels $(0 \cdot 3 \pm 0 \cdot 1 \mathrm{ng} / \mathrm{ml})$ were observed by $18 \mathrm{~h}$.

Progesterone concentrations following i.m. treatment with progesterone are illustrated in Textfig. 5. The slope of the increase in backfat values was similar to that observed during the cycle and maximal levels were reached $24 \mathrm{~h}$ after the last progesterone injection. Levels of progesterone in plasma had started to decline by $8 \mathrm{~h}$ after the last injection of progesterone.

Body composition or fat-to-lean ratio had no clear effect on the changes in backfat or plasma progesterone concentrations during the oestrous cycle, after ovariectomy or after progesterone treatment. The fat-to-lean ratio varied between $0.48: 1$ and $0 \cdot 83: 1$. There was a tendency for a delayed maximum in the plasma progesterone concentrations in gilts with a higher proportion of fat.

Of the 44 sows studied, 38 proved to be pregnant and farrowed, whereas 6 sows became oestrous again within 3-6 weeks. At 17 days after mating, mean \pm s.e.m. fat progesterone levels in pregnant and non-pregnant animals were $80.5 \pm 4.7$ and $37.7 \pm 9.7 \mathrm{ng} / 100 \mathrm{mg}$ backfat, respectively. At 20 days after mating the respective values were: $76.7 \pm 4.5$ and $7.2 \pm 1.3 \mathrm{ng}$ progesterone/100 mg backfat. On both days, the differences were statistically significant $(P \leqslant 0 \cdot 05$, Student's $t$ test).

\section{Discussion}

Our data clearly indicate that considerable amounts of progesterone are present in the backfat of the pig. Based on $150 \mathrm{~kg}$ body weight, the assumption of $40 \mathrm{~kg}$ fat tissue and a total of 6 litres blood plasma, we calculated that in the middle of the luteal phase about $36 \mathrm{mg}$ progesterone are stored in fat tissue, whereas only about $0.2 \mathrm{mg}$ progesterone are present in blood. The amount of progesterone present in fat tissue is therefore approximately 200 times that present in blood and corresponds to the daily production of the corpora lutea of the sow on Day 11 of the cycle (Brinkley \& Young, 1968).

The mechanism of progesterone storage in fat tissue and that of progesterone depletion from fat tissue has not, to our knowledge, been investigated in vivo. It appears that this transfer is not an active process. In vitro, steroids penetrate from the buffer system into the fat tissue, and the speed as 
well as the percentage of steroid penetrating are dependent on the lipophilic characteristic of the steroid (Claus, 1979). The nature of the adipose tissue also seems to affect the level of progesterone in fat. Whereas the concentrations in backfat and bacon were similar, consistently higher levels were measured in flare fat from slaughtered sows (F. Elsaesser, unpublished observation). These differences may be explained by differences in fatty acid composition or differences in blood supply.

Comparison of the changes in fat and plasma progesterone during the cycle or after ovariectomy underline the function of adipose tissue as a reservoir which protects progesterone from catabolism. The shape of the disappearance curve of progesterone from the blood after ovariectomy appears to be affected by the release of progesterone from the fat. After an initial rapid fall, a more gradual decline was observed. The exact calculation and comparison of the half-life of progesterone in fat and in plasma might, however, be confounded by the effect of anaesthesia or surgery. This effect is most obvious in the sows which had no functional corpora lutea at ovariectomy and in which plasma progesterone rose immediately after initiation of anaesthesia (Text-fig. 4). Most probably, in these circumstances progesterone is derived from the adrenal, since it has been shown that progesterone levels in ovariectomized sows may be increased by treatment with ACTH (Close \& Liptrap, 1975). Nevertheless, approximate figures can be calculated to stress the low disappearance rates of progesterone from backfat. Whereas plasma progesterone concentrations declined within 4 days to $3 \%$ of the original value, fat progesterone concentrations during this period fall only to $15 \%$. This slow decline may explain why urinary excretion of progesterone metabolites does not decrease to low levels for at least 2 weeks after ovariectomy and why a further decrease in urinary pregnane excretion was observed when Day 35 rates were compared to Day 245 rates (Brown, Erb \& Randel, 1974).

The substantial storage of progesterone in the body fat of the sow may have important implications for the plasma progesterone levels and thus for the control of the oestrous cycle. The increase in circulating plasma progesterone levels after formation of corpora lutea is delayed, short-term (episodic) fluctuations in plasma progesterone are damped, possibly the maximum levels are limited, and, most importantly, following the onset of natural or PGF- $2 \alpha$-induced luteolysis, the depletion of the fat depot will cause a delayed fall in plasma progesterone concentrations. In the pig, which has a high proportion of fat tissue and apparently a considerably longer initial half-life of plasma progesterone than does the cow, for example (5-15 min: McCracken, 1963; Hoffmann, Wagner, Rattenberger \& Schmidt, 1977), luteolysis starts quite early during the cycle, thus allowing circulating progesterone to return to basal levels for the expression of oestrous behaviour and the induction of ovulation. After artificial induction of luteolysis by PGF- $2 \alpha$, oestrus is observed in the pig 5-7 days after treatment on Day 12 or 13 of the cycle (Hallford, Wetteman, Turman \& Omtvedt, 1975; Guthrie \& Polge, 1976; Lindloff, Holtz, Elsaesser, Kreikenbaum \& Smidt, 1976) but in the cow it takes only 2-4 days to induce heat (Rowson, Tervit \& Brand, 1972; Lauderdale, 1975). It has been suggested (Baird, Baker, McNatty \& Neal, 1975) that these species differences in time intervals between functional luteolysis and ovulation of newly grown follicles are most probably related to the degree of follicular maturation at the onset of luteolysis. In addition, it is possible that the early onset of luteal regression in the pig may be related to the long half-life of progesterone and may be a precaution for those sows with a high degree of fatness. In our study differences in fat-tolean ratio did not contribute to the speed of clearance of progesterone from the depot fat or from the circulation. However, the number of animals was relatively small and the animals did not differ markedly in fat-to-lean ratios.

Changes in backfat concentrations of progesterone reflect, with delay, changes in ovarian function and the differences in fat progesterone levels between pregnant and non-pregnant animals suggest, despite the small number of animals, that the measurement of backfat progesterone could be used for pregnancy testing. Compared with the determination of progesterone in blood, which allows a reliable diagnosis of non-pregnant sows as early as 17 days after mating (Hultsch, 1980), reliable discrimination between pregnant and non-pregnant sows by means of backfat 
progesterone analysis appears to be possible on Day 19 or 20 after mating. Although the fat progesterone analysis requires more laboratory work than do blood progesterone determinations, this type of pregnancy test would offer some advantages. Compared to blood sampling from an ear vein as described by Hultsch \& Ellendorff (1979), a fat sample can be obtained faster and with less stress to the animal, so that sampling can be done from unrestrained sows kept in groups. In addition, no centrifugation and less experience in sampling technique is necessary and there is no risk of injury to the farmer. However, as with all pregnancy tests which need laboratory analysis, the test is expensive and the result will not be available to the farmer for 24-48 h.

The expert technical assistance of Mrs U. Buntrock and Miss R. Ronge is gratefully acknowledged.

\section{References}

Baird, D.T., Baker, T.G., McNatty, K.P. \& Neal, P. (1975) Relationship between the secretion of the corpus luteum and the length of the follicular phase of the ovarian cycle. J. Reprod. Fert. 45, 611-619.

Brinkley, H.J. \& Young, E.P. (1968) Determination of the in-vivo rate of progesterone secretion by the ovary of the pig during the luteal phase of the estrous cycle. Endocrinology 82, 203-208.

Brown, B.L., Erb, R.E. \& Randel, R.D. (1974) Reproductive hormones in blood and urine of ovariectomized sows. J. Anim. Sci. 39, 606-611.

Claus, R. (1979) Pheromone bei Säugetieren unter besonderer Berücksichtigung des Ebergeruchstoffes und seiner Beziehung zu anderen Hoden-Steroiden. Z. Tierphysiol. Tierernähr. Futtermittelkd., Beiheft 10.

Close, R.W. \& Liptrap, R.M. (1975) Plasma progesterone levels in sows with induced cystic ovarian follicles. Res. vet. Sci. 19, 28-34.

Ellendorff, F., Parvizi, N., Elsaesser, F. \& Smidt, D. (1977) The miniature pig as an animal model in endocrine and neuroendocrine studies of reproduction. Lab. Anim. Sci. 27, 822-830.

Foxcroft, G.R. \& van de Wiel, D.F.M. (1982) Endocrine control of the oestrous cycle. In Control of Pig Reproduction, pp. 161-177. Eds D. J. A. Cole \& G. R. Foxcroft. Butterworth Scientific, London.

Gomes, W.R., Herschler, R.C. \& Erb, R.E. (1965) Progesterone levels in ovarian venous effluent of the non-pregnant sow. J. Anim. Sci. 24, 722-725.

Guthrie, H.D. \& Polge, C. (1976) Luteal function and oestrus in gilts treated with synthetic analogue of prostaglandin F-2 $\alpha$ (ICI 79,939) at various times during the oestrous cycle. J. Reprod. Fert. 48, 423425.

Hallford, D.M., Wetteman, R.P., Turman, E.J. \& Omtvedt, I.T. (1975) Luteal function in gilts after prostaglandin F-2 $\alpha$. J. Anim. Sci. 41, 1706-1710.

Hoffmann, B., Wagner, W.C., Rattenberger, E. \& Schmidt, J. (1977) Endocrine relationships during late gestation and parturition in the cow. In The Foetus at Birth (Ciba Fdn Symp. No. 47 (new series)), pp. 107-125. Elsevier, Excerpta Medica, North Holland, Amsterdam.
Hultsch, K.H. (1980) Der Einsatz des Progesteron-Tests zum Trächtigkeits- und Fertilitätsnachweis beim Schwein unter praktischen Bedingungen. Ph.D. thesis, University of Göttingen.

Hultsch, K.H. \& Ellendorff, F. (1979) Ein neues Verfahren zur Blutentnahme beim Schwein. Dtsch. tierärztl. Wschr. 86, 293-332.

Kallweit, E. (1978) Vermarktung und Qualitäts-ansprüche bei Schlachtschweinen. In Schweinezucht, $\mathrm{p}$. 470. Ed. G. Comberg. Eugen Ulmer, Stuttgart.

Kaufmann, C. \& Zander, J. (1956) Progesteron im menschlichen Blut und Gewebe. II. Mitteilung: Progesteron im Fettgewebe. Klin. Wschr. 34, 7-9.

Lauderdale, J.W. (1975) The use of prostaglandin in cattle. Annls Biol. anim. Biochim. Biophys. 15, 419425 .

Lindloff, G., Holtz, W., Elsaesser, F., Kreikenbaum, K. \& Smidt, D. (1976) The effect of prostaglandin $F_{2 \alpha}$ on corpus luteum function in the Göttingen miniature pig. Biol. Reprod. 15, 303-310.

Masuda, H., Anderson, L.L., Henricks, D.M. \& Melampy, R.M. (1967) Progesterone in ovarian venous plasma and corpora lutea of the pig. Endocrinology 80, 240-246.

McCracken, J.A. (1963) Plasma progesterone concentration after removal of the corpus luteum in the cow. Nature, Lond. 198, 507-508.

McCracken, J.A. (1964) Progesterone in the body fat of the dairy cow. J. Endocr. 28, 339-340.

Parvizi, N., Elsaesser, F., Smidt, D. \& Ellendorf, F. (1976) Plasma luteinizing hormone and progesterone in the adult female pig during the oestrous cycle, late pregnancy and lactation, and after ovariectomy and pentobarbitone treatment. J. Endocr. 69, 193-203.

Rowson, L.E.A., Tervit, R. \& Brand, A. (1972) Synchronization of oestrus in cattle by means of prostaglandin. Proc. 7th Int. Congr. Anim. Reprod. \& A.I., Munich, II, 865-869.

Schmidt, J., Hoffmann, B. \& Rattenberger, E. (1977) Role of corpus luteum function in the cow as it relates to parturition. Acta endocr., Copenh., Suppl. 212, 128, Abstr. 